Research Article

\title{
Identifying Causes of Vaginal Discharge: The Role of Gynecologic Symptoms and Signs
}

\section{Upaya Diagnosis Penyebab Keputihan: Peran dari Gejala dan Tanda Ginekologi}

\author{
Farhan D Hasan, Dwiana Ocviyanti \\ Department of Obstetrics and Gynecology \\ Faculty of Medicine University of Indonesia/ \\ Dr. Cipto Mangunkusumo Hospital \\ Jakarta
}

\begin{abstract}
Objective: To attain diagnostic accuracy of various gynecologic symptoms and signs in identifying causes of vaginal discharge.

Method: Eighty-two subjects were included in this cross sectional study. Gynecologic symptoms and signs were inquired from each subject and further laboratory examinations were carried out to identify the etiology. Diagnostic accuracy for each symptom and sign was compared to the laboratory examination as the standard reference. Symptoms and signs with positive predictive value (PPV) of more than $50 \%$ were considered to have good diagnostic accuracy.
\end{abstract}

Result: For bacterial vaginosis, excessive wetness in genital area; vulvar maceration; and thin, turbid, yellowish vaginal discharge had PPVs of 53\%; 52\%; and 52\%, respectively. For candidal vaginitis, vulvar maceration; and white, curd-like vaginal discharge had PPVs of $58 \%$ and $100 \%$, respectively. For trichomoniasis, thin, turbid, frothy, yellowish vaginal discharge; and strawberry-cervix appearance had PPVs of $60 \%$ and $100 \%$, respectively. There were no symptoms or signs with PPV of more than $50 \%$ for chlamydial cervicitis. Diagnostic accuracy for clinical findings in gonorrheal cervicitis could not be calculated due to the small number of subjects.

Conclusion: Various gynecologic symptoms and signs were found to be accurate in diagnosing bacterial vaginosis, candidal vaginitis, and trichomoniasis. No symptoms or signs were considered accurate to aid etiological diagnosis for chlamydial and gonorrheal cervicitis.

[Indones J Obstet Gynecol 2015; 1: 3-10]

Keywords: bacterial vaginosis, Candida sp, Chlamydia trachomatis, gynecologic symptoms and signs, Neisseria gonorrhoeae, Trichomonas vaginalis

\begin{abstract}
Abstrak
Tujuan: Untuk memperoleh akurasi diagnostik dari gejala dan tanda ginekologi dalam menentukan penyebab keputihan.

Metode: Pada studi potong lintang ini, diteliti 82 subjek penelitian. Pada seluruh subjek dilakukan pemeriksaan gejala dan tanda ginekologis, serta dilakukan pemeriksaan laboratorium untuk menentukan etiologi keputihan. Akurasi diagnostik berbagai temuan klinis ditentukan berdasarkan referensi standar pemeriksaan laboratorium. Temuan klinis dengan nilai PPV lebih dari 50\% dianggap memiliki akurasi diagnostik yang baik.
\end{abstract}

Hasil: Rasa basah berlebih, maserasi vulva, dan fluor keruh kekuningan encer memiliki PPV masing-masing 53\%, 52\%, dan 52\% untuk bacterial vaginosis. Maserasi vulva dan fluor putih bergumpal memiliki PPV masing-masing 58\% dan 100\% untuk vaginitis akibat Candida sp. Fluor keruh, encer, kekuningan, berbuih dan serviks dengan bercak merah (strawberry cervix) memiliki PPV masing-masing 60\% dan 100\% untuk vaginitis akibat T. vaginalis. Tidak terdapat temuan klinis dengan PPV di atas 50\% untuk servisitis akibat C.trachomatis. Untuk subjek yang terinfeksi N.gonorrhoeae, akurasi diagnostik tidak dapat ditentukan karena sedikitnya jumlah subjek dengan kasus tersebut.

Kesimpulan: Berbagai temuan klinis pada pemeriksaan ginekologis memiliki akurasi diagnosis yang baik untuk kasus bakterial vaginosis, vaginitis candida, dan trikomoniasis. Untuk infeksi C.trachomatis dan N.gonorrhoeae tidak ditemukan gejala dan tanda klinis dengan akurasi diagnostik baik.

[Maj Obstet Ginekol Indones 2015; 1: 3-10]

Kata kunci: bakterial vaginosis, Candida sp, Chlamydia trachomatis, gejala dan tanda ginekologi, Neisseria gonorrhoeae, Trichomonas vaginalis

Correspondence: Farhan D Hasan. Department of Obstetrics and Gynecology, Faculty of Medicine, University of Indonesia. Jalan Salemba Raya No. 6, Jakarta Pusat 10430, Indonesia. E-mail: farhandjamal@yahoo.com.

\section{INTRODUCTION}

The presence of vaginal discharge is among the most common problems reported by women who seek treatment at health care facilities. ${ }^{1,2}$ It may also be a predictor of sexually transmitted infection in women. ${ }^{3}$ Infection due to Neisseria gonorrhoeae (gonorrheal cervicitis), Chlamydia trachomatis (chlamydial cervicitis), Candida sp. (candidal vaginitis), Trichomonas vaginalis (trichomoniasis), and bacterial vaginosis are the most common causes of vagi- nal discharge, which may present with similar clinical manifestations. ${ }^{4-7}$

Previous studies have reported various clinical manifestations of each mentioned causes of vaginal discharge. In trichomoniasis, gynecological symptoms consist of malodorous vaginal discharge and vulvar discomfort, with signs of vaginal redness, red spots on the cervix (strawberry-cervix appearance), and thin, frothy, turbid, yellowish vaginal discharge. $^{3}$ In bacterial vaginosis, symptoms con- 
sist of malodorous vaginal discharge and excessive wetness in the genital area, with signs of vulvar maceration/redness and thin, turbid, yellowish vaginal discharge..$^{3-5}$ In cases of candidal vaginitis, gynecological symptoms encompass malodorous vaginal discharge, itchiness in the vulvar area, and pain during sexual intercourse, with signs of genital maceration, vaginal redness, and white, curd-like vaginal discharge. ${ }^{3-5}$ In cases of chlamydial cervicitis, reported symptoms include pain during sexual intercourse and vaginal bleeding after sexual intercourse, with signs of ectopic cervix. Previous studies on gonorrheal cervicitis reported gynecologic symptoms of vaginal bleeding between usual menstrual cycles, pain during sexual intercourse, and pain during urination, with signs of purulent cervical discharge. ${ }^{6-7}$ However, the aforementioned symptoms and signs are generally found in patients complaining of vaginal discharge.

In primary health care facilities, or facilities with limited resources, laboratory examinations to confirm the cause of infection are often expensive or not readily accessible. In these settings, clinical examination, consisting of gynecological symptoms and signs, play a major role in establishing the etiological diagnosis. Therefore, this research aims to study the diagnostic accuracy of the various aforementioned clinical findings in confirming the etiological diagnosis of vaginal discharge due to bacterial vaginosis, $N$. gonorrhea, C. trachomatis, Candida sp., and T. vaginalis.

\section{METHODS}

This cross-sectional, diagnostic study was conducted in the Obstetrics and Gynecology outpatient clinic in Dr. Cipto Mangunkusumo National Hospital and in several private, primary-care clinics in Jakarta, during the period of May 2012 until June 2013. Research subjects consisted of women of reproductive age (15-49 years old) with the chief complaint of having vaginal discharge, were sexually active, had an initial vaginal-discharge discomfort score of $\geq 5$, and expressed written consent to participate in this study. Women were excluded if they were pregnant, in puerperium, having her menstrual period at time of presentation, having a history of conditions causing an immunocompromised state (diabetes mellitus, HIV infection); is being treated for vaginal discharge; and having a history of malignancy which had been treated with chemotherapy or radiation. Research sample size was calculated using the formula for diagnostic studies, which yielded the minimum number of 202 subjects. Consecutive sampling method was utilized to reach the required number of subjects.

Eligible subjects who gave their written consent were examined by trained obstetrics-gynecology residents in a blinded manner. Clinical examination included gynecological history taking and physical examination (encompassing the vulva, vagina, and cervix). Results from clinical examination were documented in standardized forms. For photographic documentation purpose, subjects' external genital, vaginal canal, and cervix were photographed using a 5 megapixel digital camera.

For laboratory examination, subjects' vaginal and cervical discharge samples were collected using sterile swabs. Discharge samples were prepared, utilizing appropriate methods and transport media before being sent to Parasitology Laboratory (for Candida sp. and T. vaginalis confirmation) and Microbiology Laboratory (for bacterial vaginosis, $N$. gonorrhea, and C. trachomatis confirmation) in the Faculty of Medicine, University of Indonesia. For $N$. gonorrhea and C. trachomatis diagnosis, specific swabs from Roche Diagnostic System Kit were utilized. Discharge samples were examined by experienced laboratory technicians, using the wet mount method for Candida sp. and T. vaginalis identification, Gram stain (using Nugent criteria) for bacterial vaginosis confirmation, and polymerase chain reaction using Cobas Amplicor (Roche) for $N$. gonorrhea and C. trachomatis. Following vaginal discharge sample collection, subjects were treated in accordance to the WHO guideline for vaginal discharge. ${ }^{7,8}$ On the following week, subjects were informed about the laboratory examination result and if complaints persisted, treatment regiments were adjusted to the result.

Data analysis was performed using Stata version 12 software. From the cross-tabulation, values for sensitivity, specificity, positive predictive value (PPV), and negative predictive value (NPV) for each symptom or sign was calculated. Diagnostic accuracy for a given symptom or sign was considered accurate for a PPV of more than $50 \%$. Ethical clearance for this study had been approved by the Ethical Committee, Faculty of Medicine, University of Indonesia. 


\section{RESULTS}

From 188 subjects who had a chief complaint of vaginal discharge, 82 of which were eligible to be included in this study. Research subjects' characteristics are presented in Table 1.
Aside of the chief complaint, a thorough gynecological examination was also performed on the subjects. Distribution of gynecological symptoms and signs are presented in Table 2.

Table 1. Subject Characteristics

\begin{tabular}{|c|c|}
\hline Characteristics & Number of Subjects (\%) \\
\hline \multicolumn{2}{|l|}{ Age Group (years) } \\
\hline $15-19$ & $1(1.2)$ \\
\hline $20-29$ & $29(35.4)$ \\
\hline $30-39$ & $36(43.9)$ \\
\hline $40-49$ & $16(19.5)$ \\
\hline \multicolumn{2}{|l|}{ Education } \\
\hline No formal education & $2(2.4)$ \\
\hline Elementary school graduate & $5(6.1)$ \\
\hline Junior high school graduate & $13(15.9)$ \\
\hline Senior high school graduate & $36(43.9)$ \\
\hline D1 graduate & $1(1.2)$ \\
\hline D3 graduate & $7(8.6)$ \\
\hline S1 graduate & 17 (20.7) \\
\hline S2 graduate & $1(1.2)$ \\
\hline \multicolumn{2}{|l|}{ Occupation } \\
\hline Teacher/lecturer & $4(4.9)$ \\
\hline Housewife & $42(51.2)$ \\
\hline Employee (private sector) & $21(25.6)$ \\
\hline University student & $1(1.2)$ \\
\hline Civil servant & $7(8.6)$ \\
\hline Self-employed & $7(8.6)$ \\
\hline \multicolumn{2}{|l|}{ Contraceptive method } \\
\hline IUD & $10(12.2)$ \\
\hline Condom & $15(18.3)$ \\
\hline Combination pill & $14(17.1)$ \\
\hline Hormone injection per 3 months & $4(4.9)$ \\
\hline Hormone injection per 1 month & $3(3.7)$ \\
\hline None & $36(43.9)$ \\
\hline \multicolumn{2}{|l|}{ Marital Status } \\
\hline Widowed & $6(7.3)$ \\
\hline Married & $76(92.7)$ \\
\hline \multicolumn{2}{|c|}{ Different Sex Partner in the Previous Month } \\
\hline Yes & $13(15.9)$ \\
\hline No & $69(84.1)$ \\
\hline
\end{tabular}


Table 2. Distribution of Clinical Findings among Subjects with Vaginal Discharge

\begin{tabular}{lc}
\hline \hline Clinical Findings & Number of Subjects (\%) \\
\hline Symptoms & $58(70.7)$ \\
Excessive wetness & $56(68.3)$ \\
Itchiness & $55(67.1)$ \\
Malodorous discharge & $22(26.8)$ \\
Pain during sexual intercourse & $20(24.4)$ \\
Vulvar discomfort & $12(14.6)$ \\
Bleeding after sexual intercourse & $7(8.5)$ \\
Pain during urination & $2(2.4)$ \\
Bleeding between menstrual periods & \\
Signs & $64(78.0)$ \\
Thin, turbid, yellowish vaginal discharge & $43(52.4)$ \\
Vaginal redness & $31(37.8)$ \\
Vulvar maceration & $29(35.4)$ \\
Ectopic cervix & $7(8.5)$ \\
Red spots on cervix (strawberry-cervix appearance) & $5(6.1)$ \\
Thin, frothy, turbid, yellowish vaginal discharge & $5(6.1)$ \\
White, curd-like vaginal discharge & $5(6.1)$ \\
Purulent cervical discharge &
\end{tabular}

On gynecological examination, it was found that 15 subjects $(18.3 \%)$ had thin, clear vaginal discharge, 36 subjects (43.9\%) had smooth cervical appearance, 9 subjects (11.0\%) had reddish cervical appearance, and 77 subjects (93.9\%) were found to have clear cervical discharge.
To identify the causative agents, subjects' vaginal and cervical discharge samples were also examined in the microbiology and parasitology laboratory. Findings from the laboratory examination are presented in Table 3.

Table 3. Distribution of Laboratory Findings from Subjects' Vaginal and Cervical Discharge Samples

\begin{tabular}{lc}
\hline \hline Etiology & Number of Cases (\%) \\
\hline Singular Etiology & \\
Bacterial vaginosis & $11(13.4)$ \\
Candida sp. & $6(7.3)$ \\
C. trachomatis & $6(7.3)$ \\
T. vaginalis & $4(4.9)$ \\
N. gonorrhoeae & $0(0)$ \\
Multiple Etiologies & \\
Bacterial vaginosis, Candida sp. & $13(15.9)$ \\
Bacterial vaginosis, C. trachomatis & $3(3.7)$ \\
Bacterial vaginosis, T. vaginalis & $2(2.4)$ \\
Bacterial vaginosis, N. gonorrhoeae & $1(1.2)$ \\
Candida sp, T. vaginalis & $5(6.1)$ \\
T. vaginalis, C. trachomatis & $1(1.2)$ \\
Bacterial vaginosis, Candida sp., T. vaginalis & $5(6.1)$ \\
Bacterial vaginosis, Candida sp., C. trachomatis & $1(1.2)$ \\
Bacterial vaginosis, Candida sp., N. gonorrhoeae & $1(1.2)$ \\
\hline Total & $59(71.9)$ \\
\hline \hline
\end{tabular}


From Table 3, the most common cause of vaginal discharge is concurrent bacterial vaginosis and Candida sp. infection, followed by singular etiology of bacterial vaginosis. Among subjects, there was no singular infection of $\mathrm{N}$. gonorrhoea. The two subjects with $\mathrm{N}$. gonorrhoea infection had co-infection with other microorganisms. From the results of laboratory examination, 37 subjects $(45.12 \%)$ had bacterial vaginosis, 31 subjects $(37.8 \%)$ were infected by Candida sp, 17 subjects $(20.7 \%)$ were infected by $\mathrm{T}$. vaginalis, 11 subjects $(13.4 \%)$ were infected by C. trachomatis, and only 2 subjects $(2.4$ $\%$ ) were infected by N. gonorrhoeae, either occurring as single or multiple infections.

This study was conducted to assess diagnostic accuracy of any presenting gynecological symptoms and signs found in the subjects. Diagnostic accuracy for each clinical manifestation is presented in its PPV, NPV, sensitivity, and specificity values. Symptoms or signs having a PPV more than $50 \%$ were considered accurate from a diagnostic point of view in guiding the identification of the cause of vaginal discharge. Diagnostic accuracy values for each presenting symptoms and signs, according to the causative organism, are presented in Table 4.

Of particular note, diagnostic accuracy for subjects with N. gonorrhea infection could not be calculated, as there were only two subjects with gonorrheal cervicitis. Both subjects had clinical findings of pain during urination and purulent cervical discharge. Neither had pain during sexual intercourse, nor vaginal bleeding between menstrual cycles.

Table 4. Diagnostic Accuracy Values for Each Symptoms and Signs

\begin{tabular}{|c|c|c|c|c|c|}
\hline \multicolumn{2}{|c|}{ Clinical Findings } & $\%$ Se $(95 \% \mathrm{CI})$ & $\% \mathrm{Sp}(95 \% \mathrm{CI})$ & \% PPV (95\% CI) & $\%$ NPV $(95 \% \mathrm{CI})$ \\
\hline \multicolumn{6}{|c|}{ Bacterial vaginosis } \\
\hline \multirow[t]{2}{*}{ Symptoms } & Malodorous discharge & $70(53-84)$ & $34(20-50)$ & $47(34-58)$ & $58(37-77)$ \\
\hline & Excessive wetness & $82(65-92)$ & $39(24-54)$ & $53(40-66)$ & $71(49-87)$ \\
\hline \multirow[t]{2}{*}{ Signs } & Vulvar maceration & $43(27-60)$ & $66(50-79)$ & $52(33-70)$ & $58(43-72)$ \\
\hline & Thin, turbid, yellowish vaginal discharge & 89 (75-97) & $29(17-45)$ & $52(39-64)$ & $54(50-93)$ \\
\hline \multicolumn{6}{|c|}{ Candidal vaginitis } \\
\hline \multirow[t]{3}{*}{ Symptoms } & Malodorous discharge & $68(47-83)$ & $32(19-46)$ & $38(25-52)$ & $61(41-79)$ \\
\hline & Pain during sexual intercourse & $19(7.6-37)$ & $68(53-80)$ & $27(11-50)$ & $58(44-70)$ \\
\hline & Itchiness & $84(66-94)$ & $40(26-54)$ & $46(33-60)$ & $80(59-93)$ \\
\hline \multirow[t]{3}{*}{ Signs } & Vulvar maceration & $58(39-75)$ & $74(60-85)$ & $58(40-75)$ & $74(60-85)$ \\
\hline & White, curd-like vaginal discharge & $16.1(5-33)$ & 100 & 100 & $66(54-76)$ \\
\hline & Vaginal redness & $64(45-82)$ & $54(39-68)$ & $46(31-62)$ & $71(54-85)$ \\
\hline \multicolumn{6}{|c|}{ Trichomoniasis } \\
\hline \multirow[t]{3}{*}{ Symptoms } & Malodorous discharge & $94(71-99)$ & $39(27-52)$ & $29(18-43)$ & $96(80-99)$ \\
\hline & Vulvar discomfort & $47(23-72)$ & $82(69-89)$ & $40(19-64)$ & $85(74-93)$ \\
\hline & Thin, frothy, turbid, yellowish vaginal discharge & $18(4-43)$ & 97 (89-99) & $60(15-94)$ & $82(71-89)$ \\
\hline \multirow[t]{2}{*}{ Signs } & Red spots on cervix (strawberry-cervix appearance) & $41(18-67)$ & 100 & 100 & $86(76-93)$ \\
\hline & Vaginal redness & 47 (28-77) & $56(34-59)$ & $21(10-36)$ & $85(63-90)$ \\
\hline \multicolumn{6}{|c|}{ Chlamydial cervicitis } \\
\hline \multirow[t]{2}{*}{ Symptoms } & Pain during sexual intercourse & 45 (17-77) & $76(64-85)$ & $23(8-45)$ & $90(45-79)$ \\
\hline & Bleeding after sexual intercourse & 45 (17-77) & $90(80-96)$ & $42(15-72)$ & 91 (82-97) \\
\hline Signs & Ectopic cervix & $62(31-90)$ & $68(55-79)$ & $23(13-34)$ & $92(82-98)$ \\
\hline
\end{tabular}




\section{DISCUSSION}

Diagnostic accuracy of various clinical findings is stated in terms of PPV, NPV, sensitivity, and specificity values. While sensitivity and specificity are more useful for screening purpose, PPV is considered more significant in determining diagnostic power. Therefore our discussion is focused on the PPV of various clinical findings associated with the occurrence of pathologic vaginal discharge.

For bacterial vaginosis, a major proportion of subjects $(67.1 \%)$ had malodorous discharge as a presenting symptom (PPV 41.2\%). In bacterial vaginosis, a shift in normal vaginal flora dominance occurs, where anaerobic bacteria predominates. ${ }^{9}$ Anaerobes convert amino acids in the vaginal secretions to amine compounds (putrescine, cadaverine, triethylamine), which causes a characteristic fishy-odor discharge; similar to that in T. vaginalis infection. ${ }^{3,4}$ Malodorous discharge can also be found in candida vaginitis, however the odor resembles the odor of sour milk, thus it differs from that of bacterial vaginosis. Excessive wetness was found in $70.7 \%$ subjects (PPV 53\%). This symptom is caused due to excessive production of vaginal secretions, and may also be present in cases of allergy or other causes of infection. However, this symptom does not directly correlate with bacterial vaginosis, due to its low specificity value. Overproduction of vaginal secretions may also causes maceration of the vulvar skin. This finding is not directly caused by the presence of offending microorganism, but due to the overabundance of vaginal secretions. Therefore, although $37.8 \%$ subjects had this finding (with PPV of 52\%), vulvar maceration is not an accurate clinical indicator of bacterial vaginosis. In term of the vaginal discharge itself, thin, turbid, yellowish discharge was found on $78.0 \%$ subjects (PPV 52\%). Such vaginal discharge is caused by exfoliation of the vaginal ephitelium, along with exudative matters. ${ }^{4}$ Although some clinical findings had PPV of more than 50\%, they are not specific for bacterial vaginosis. Consequently, there are no pathognomonic clinical findings for bacterial vaginosis, and a combination of aforementioned symptoms and signs is needed to make an accurate etiological diagnosis.

In this study, candidal vaginitis was identified in 31 subjects $(37.8 \%)$; 6 cases occurred as a freestanding Candida sp. infection. Malodorous discharge, which in candidal vaginitis is often described as having a sour-milk odor, was reported by a majority of subjects (68\% subjects; PPV 38\%). Pain during sexual intercourse was reported by 22 subjects $(26.8 \%)$, with a PPV of $27.3 \%$. Pain is caused by vaginal inflammation due to the infectious process. Other types of infections, such as chlamydial cervicitis and gonorrheal cervicitis, are often accompanied by pain during intercourse as well. However, in candidal vaginitis, pain is often reported as being superficial in nature, while in chlamydial and gonorrheal cervicitis, the pain is felt deeper. ${ }^{3}$ Other symptom that was reported by a majority of subjects was itchiness, with $68.3 \%$ subjects reporting this symptom (PPV 46\%). The hyphae of Candida sp. grow in the subepithelial layer, causing exfoliation of vaginal epithelium and itchiness. ${ }^{10}$ Among those symptoms, none was noted to have good diagnostic accuracy for candidal vaginitis. For gynecological signs, vulvar maceration, found in $37.8 \%$ of subjects, had a PPV of $58 \%$, while white curd-like vaginal discharge was found in $6.1 \%$ of subjects (PPV 100\%), and vaginal redness was found in $52.4 \%$ of subjects, with PPV of $46 \%$. Even though vulvar maceration has a good diagnostic accuracy, it is not specific for candidal vaginitis. On the other hand, the characteristic vaginal discharge is considered very specific for candidal vaginitis. Another sign, vaginal redness, was found in $52.4 \%$ subjects, with PPV of $46 \%$, and deemed not having significant diagnostic accuracy.

T. vaginalis was found as the causative organism in 17 subjects (20.7\%). Malodorous vaginal discharge was reported by 55 subjects (68\%, PPV $29 \%$ ). This symptom also had a low specificity value for trichomoniasis, making it not characteristic for T. vaginalis infection. Vulvar pain, which is caused by inflammatory reaction generated by T. vaginalis invasion in the vaginal epithelium, ${ }^{4}$ is reported by 20 subjects (24\%). It should also be noted that allergic reaction due to certain vaginaldouching agents, panty liners, or other substances, may also cause pain in the vulvar area. ${ }^{4,11}$ Vaginal redness was found in 43 subjects, with PPV of $21 \%$. Redness is caused by a non-specific reaction to infection or allergy, and is not pathognomonic for trichomoniasis. On the other hand, findings of thin, frothy, turbid, yellowish vaginal discharge (5 subjects, PPV 60\%, specificity 97\%) and strawberrycervix appearance (7 subjects, PPV 100\%) are considered accurate for the diagnosis of trichomoniasis. T. vaginalis metabolism produces $\mathrm{CO}_{2}$ and $\mathrm{H}_{2}$ gasses in copious amount, especially in the presence of high vaginal $\mathrm{pH}$. This produces the frothy 
vaginal discharge in patients with trichomoniasis. ${ }^{4}$ On the cervix, subepithelial cervical bleeding causes red spots on the cervix commonly known as strawberry-cervix appearance. This finding is the hallmark of $T$. vaginalis infection, and serves as a strong clinical indicator of trichomoniasis. ${ }^{3,5,8}$ However, the absence of this finding does not directly rule out $T$. vaginalis infection.

This study identified 11 subjects (13.4\%) with chlamydial cervicitis, of which 6 cases occurred as a freestanding $C$. trachomatis infection. Twenty two subjects $(26.8 \%)$ reported pain during sexual intercourse (PPV 23\%). While deep dyspareunia is commonly reported in patients with chlamydial cervicitis, other causes of pelvic inflammation may also cause a similar symptom, ranging from gonorrheal cervicitis, fungal infection, to psychological problems. ${ }^{3}$ Further, as the inflammation is mainly occurring on the cervix, C. trachomatis infection also causes cervical redness due to the inflammatory process, increased cervical tissue friability, and hyperplasia of the cervical tissue (ectopic cervix). These findings may also be found on cases of cervical neoplasia. ${ }^{5}$ Therefore, it is important to seek which findings are considered accurate for chlamydial cervicitis. Post-coital vaginal bleeding was reported by 12 subjects (14.6\%, PPV 41.7\%), while ectopic cervix was found in 30 subjects (36.6\%, PPV 23\%). Both findings were considered inaccurate to diagnose chlamydial cervicitis, as the PPV is below $50 \%$. Previous studies also found that there are no characteristic findings in chlamydial cervicitis. Therefore, laboratory examination is warranted when the patient has risk factors for $C$. trachomatis infection. In populations with high risk of $C$. trachomatis infection, WHO also suggest syndromic management of sexually transmitted infection, which advocates prompt treatment of chlamydial cervicitis without waiting for the laboratory examination result.7,8

Gonorrhoeal cervicitis was found in only 2 subjects, both in combination with other causative agents. This hinders the calculation of diagnostic accuracy for clinical indicators in subjects with gonorrheal cervicitis. The low number of cases might be due to several reasons. First, the prevalence for gonorrheal cervicitis that we used is obtained from a previous study, which was conducted in Indonesia, but on high-risk population. ${ }^{12,13}$ Therefore, it is possible that the prevalence of gonorrheal cervicitis in the general population is much lower than that in the high-risk population. We also utilized
PCR method in detecting the presence of N. gonorrhea. The sensitivity of PCR examination reaches $90 \%$. Therefore, a slight possibility of false negative still exists. Ideally, a selective culture medium, such as the Thayer-Martin agar, is utilized. ${ }^{14}$ However, as such culture media is difficult to obtain in Indonesia, we used the PCR method. On both subjects with gonorrheal cervicitis, pain during urination and purulent cervical discharge were found. To assess the diagnostic accuracy of both clinical findings, a higher number of subjects with gonorrheal cervicitis is required.

Of the 82 subjects, laboratory examination yielded negative results on 23 subjects. Among those subjects, clinical findings consisted of itchiness (15 subjects), excessive wetness (11 subjects), and thin, turbid, yellowish vaginal discharge $(15$ subjects). For the laboratory-negative results, probabilities of false negative results and non-infectious causes of vaginal discharge, especially allergy, can also be considered. Ectopic cervix, which is usually related to chlamydial cervicitis, was found on 9 subjects with negative laboratory examination result. Coincidentally, all 9 subjects had been using hormonal contraceptives while data collection was performed. While ectopic cervix may also be caused by chronic inflammation due to the mechanical effect of IUD; hormonal effect, either due to hormonal contraceptives or pregnancy, may also cause hyperplasia of the endocervical glands. ${ }^{15}$ The presence of ectopic cervix is associated with the occurrence of cervicitis. Furthermore, as 20 other subjects (68.9\% of subjects with ectopic cervix) with ectopic cervix were found to be infected with a single or multiple causative agents, the presence of cervical ectopy warrants further investigation to determine the specific cause of cervicitis in the setting of negative laboratory examination results.

\section{CONCLUSIONS}

Diagnostic accuracy of various gynecological symptoms and signs are discovered through this study, which may be utilized to identify the cause of vaginal discharge among subjects. Vulvar maceration, excessive wetness in genital area, and thin, turbid, yellowish vaginal discharge have excellent diagnostic accuracy for bacterial vaginosis, while malodorous discharge is deemed not accurate. For candidal vaginitis, vulvar maceration and white, curd-like vaginal discharge are considered accurate for diagnosis. Conversely, malodorous discharge, itchiness, 
vaginal redness, and excessive wetness in genital area are not characteristic for infection caused by Candida $s p$. In trichomoniasis, the findings of thin, frothy, turbid, yellowish vaginal discharge and strawberry-cervix appearance have excellent diagnostic accuracy to aid diagnosis, while malodorous discharge, vulvar discomfort, and vaginal redness are not considered accurate.

For cervicitis, either caused by $C$. trachomatis or $N$. gonorrhea, no specific clinical symptoms or signs are considered characteristic to aid etiological diagnosis. In cases of gonorhhoeal cervicitis, pain during urination and purulent cervical discharge were consistently found among subjects. However, diagnostic accuracy for both clinical findings could not be calculated due to the small sample size for gonorrheal cervicitis.

Due to the high prevalence of vaginal or cervical infection, and the absence of clinical indicators which are diagnostically accurate for chlamydial cervicitis, specific therapy for $C$. trachomatis infection should be given in women of reproductive age who are sexually active, in accordance to WHO presumptive therapy regiment. On the other hand, therapy for bacterial vaginosis and candidal vaginitis should also be considered in women with vaginal discharge, who are in their reproductive age and are sexually active, due to the high incidence of both conditions.

\section{REFERENCES}

1. Sonnex C. Sexual health and genital medicine in clinical practice. London: Springer Science. 2007.
2. Pernoll ML. Benson and Pernoll's Handbook of Obstetric and Gynecology. 10 $10^{\text {th }}$ ed. New York: McGraw-Hill; 2001.

3. Adler M. ABC of sexually transmitted infection. $5^{\text {th }}$ ed. London: BMJ Publishing Group Ltd; 2004.

4. Gilles R, Monif G. Infectious disease in obstetric and gynaecology. $5^{\text {th }}$ ed. New York: The Parthenon Publishing Group; 2004.

5. Richard L, Ronald S. Infectious diseases of the female genital tract. $4^{\text {th }}$ ed. New York: Lippincott Williams and Wilkins; 2002.

6. Rosevear S. Handbook of gynaecology management. $1^{\text {st }} \mathrm{ed}$. Auckland: Blackwell Science; 2002.

7. World Health Organization. Global strategy for the prevention and control of sexually transmitted infections: 20062015: Breaking the chain of transmission. Geneva: World Health Organization Press; 2007.

8. World Health Organization. Training modules for the syndromic management of sexually transmitted infections, $2^{\text {nd }}$ ed. Geneva: World Health Organization Press; 2007.

9. Donders GG. Definition and classification of abnormal vaginal flora. Best Pract Res Clin Obstet Gynecol 2007; 21(3): 355-73

10. Berek JS. Berek and Novak's gynecology. $14^{\text {th }}$ ed. New York: Lippincott Williams and Wilkins; 2007.

11. Syed TS, Braverman PK. Vaginitis in adolescent. Adolesc Med 2004; 240 (15): 235-51

12. Endang RM. Validasi pemeriksaan infeksi menular seksual secara pendekatan sindrom pada kelompok wanita berperilaku risiko tinggi. Jakarta: Litbangkes; 2000.

13. Departemen Ilmu Kulit dan Kelamin FKUI. Data kasus baru IMS, Poliklinik IMS Dr. Cipto Mangunkusumo. Jakarta: Departemen Ilmu Kulit dan Kelamin FKUI. 2010.

14. Jordan JA, Singer A. The cervix. $2^{\text {nd }}$ ed. 5(16): 233-6 by Blackwell Publishing Ltd; 2006.

15. Rivera A. Cervical erosion as result of infectious vaginitis. Eur J Exp Biol 2012; 2(5): 1659-63. 